\title{
Reflecting on the Human Rights of Older Persons in South Africa
}

\author{
Ndangwa $\operatorname{Noyoo}^{1}$ (iD
}

Published online: 22 September 2017

(C) Springer International Publishing AG 2017

\begin{abstract}
This paper reflects on the human rights of older persons in South Africa and considers the manner in which they are violated, despite the country having a progressive Constitution that enshrines such rights. It interrogates this paradox while taking into account South Africa's rights-based approach to service provision. In regard to older persons, South Africa's social welfare policy, which is spelt out in the White Paper for Social Welfare (Government Gazette 386, No. 18166, 1997), guides the provision of welfare services to these citizens, from a rights-based perspective. However, there seems to be a disjuncture between what is professed in the country's Constitution and social welfare policy, and what is actually happening in the daily lives of older persons. Hence, the paper critically analyzes this contradiction.
\end{abstract}

Keywords Human rights · Older persons · South Africa · Social welfare policy

\section{Introduction}

This reflective piece revisits older persons' human rights in a democratic South Africa. It is written against a backdrop of growing concerns in the country that older persons' human rights are being violated by some people (Skweyiya 2006; Davids 2013; South African Human Rights Commission 2015; Savides 2016). According to these accounts, older persons are living in perilous conditions and confronted with

Ndangwa Noyoo

ndangwa.noyoo@uct.ac.za

1 Department of Social Development, University of Cape Town, Cape Town, South Africa dangerous situations despite the country having one of the most progressive Constitutions in the world and a host of rights-based policies and legislation. First, merely having a Constitution with a Bill of Rights and policies that are rights-based is not an end in itself in so far as the guaranteeing of the human rights of South Africans, especially older persons, is concerned. Second, broader socio-political and economic issues are central to South Africa's human rights discourse and should not be over-looked by policy-makers, social welfare practitioners, and all stakeholders who are responsible for older persons' well-being. Arguably, strict social policy measures as well as low levels of social and economic development may limit human rights fulfillment in South Africa. Therefore, the key question here is how development opportunities and inclusion are distributed in South Africa and not just having a Constitution and rightsbased policies in place. While taking into consideration the foregoing issues, older persons' human rights should not be examined in isolation, but must be located in the historical tangents of South Africa, as well as its political economy. In this regard, this paper has adopted a political economy approach for its analysis. Holden (2005, p. 178) alerts us to the fact that the political economy approach is indispensable to social policy and its analysis. He notes that once the state has intervened to whatever is considered the minimum level necessary to secure social goals, questions of distribution remain that relate to the perceived needs and interests of different social groups and classes, and therefore to political processes and struggles.

South Africa is still a society in transition and has only been democratic for 23 years. This factor is duly recognized in this paper. Therefore, older persons' human rights are taken as being at the center of the country's transitory nature. Transitional societies "may be described as those societies emerging from past and repressive regimes". Such societies 
usually "have a history of autocratic dictatorships, apartheid; periods of conflict or foreign domination. Respect for human rights is hitherto unknown or disregarded and hence such societies have to cope with the legacy of human rights abuses of the preceding repressive regimes" (Mubangizi 2005, p. 1). Also, this paper takes into account South Africa's position in the global order. Hence, the "role of capital in the theoretical model of the political economy of aging is recognized. One of the most salient contemporary debates about financial and post-industrial capital concerns globalization and the relation of old age policy to the economics and politics of markets and the power of corporate capital around the world" (Estes 2001, p. 4). Conceptually, it is worth mentioning that papers of this nature have to be sound and clear. Thus, the next section spends some time defining human rights.

\section{Unpacking Human Rights}

As a theoretical matter, the most general questions to be raised about human rights concern their nature, function, justification, and content (Holder and Reidy 2013). According to Smith $(2014$, p. 5), there are divergent views to the origins of human rights, but the existence of a body of basic rights can be traced back to early thirteenth century Europe. This has featured in various European schools of thought since that time. In many respects, the origins of human rights lie in a philosophical discourse with concepts such as liberty and even "rights." The former is linked to the constitutional concept of the rule of law - the inherent limitations on the exercise of absolute power by a sovereign, parliament, or government. However, it can be argued that human rights is not merely a European concept, as other cultures may have expressed similar notions about life but had not coined them in the same way as Europeans. This is an area that needs further exploration and is not within the scope of this paper. Nevertheless, since 1945, the span of human rights has been elaborated, and the concept now permeates the fabric of international society (Smith 2014). More importantly, these are not rights that are isolated from other rights and should be located in the general human rights narrative. Also, these are both of the country and around the world. Furthermore, human rights and fundamental freedoms are indivisible, and that the full realization of civil and political rights is impossible without the enjoyment of economic, social, and cultural rights (United Nations 1994).

Mubangizi $(2005$, p. 2) points out that human rights are usually referred to by various names and phrases. These include fundamental rights, basic rights, natural rights, or sometimes even common rights. It could be said that fundamental and/or basic rights are those rights which must be taken away by any legislation or act of the state which are often set out in the fundamental law of the country, for example the Bill of Rights in a Constitution. Human rights define the needs and also the set of rights that each individual may claim, no matter where he or she resides. This brings us to the concepts of universality (or universalism) on the one hand and indivisibility, on the other. What is important here is that the notion of universality may clash with local cultures, laws, policies, morals, and other commonly held beliefs that fail to recognize the human right in question. Indivisibility, like universality, generates controversy, as not every country has adequate resources to provide all the economic rights defined in human rights (Reichert 2011, p. 6). Therefore, it is imperative that the relationship between human rights and social rights is brought to the fore. While doing so, the distinction between a basic needs perspective and a human rights approach should also be made explicit. This is because a lot of confusion arises when people attempt to define what human rights are. For starters, the concept of social rights was initially articulated in the seminal work of T.H. Marshall (1950), when he examined the idea of citizenship. According to Marshall, citizenship has three parts, namely civil, political, and social. The civil element is composed of the rights necessary for individual freedom - liberty of the person; freedom of speech, thought, and faith; the right to own property and to conclude valid contracts; and the right to justice. Marshall observes that the last is of a different order from the others, because it is the right to defend and assert all one's rights in terms of equality with other members of society and by due process of law. Furthermore, he makes a clear distinction between social rights, and civil and political rights. To him, social rights imply an absolute right to a certain standard of civilization which is conditional only on the discharge of the general duties of citizenship. Their content, Marshall (1950) argues, does not depend on the economic value of the individual claimant.

For Marshall, citizenship connotes a status that is bestowed on those who are full members of a community. All who possess the status are equal with respect to the rights and duties with which the status entails. In summary, Marshall was able to contrast civil rights (which cover rights such as the right to the equal protection of the law), with political rights (such as the right to vote) and social rights (such as the right to receive social security) (Chesterman 2005). For authors such as Taylor-Gooby (2008, pp. 36-37), social rights, far from being a simple reflection of social progress, are twoedged in that claims in the welfare arena can be legitimated as rights in a number of ways. Thus, in practice, ideas about need, about capability, and about desert are most important. The former author explains that needs-based arguments, for instance, maintain that a class of human needs can be identified, which provide the justification for an obligation on government to ensure that these are met, so far as the current stage of development allows. However, there are a number of problems in this approach, not least in establishing a bedrock of human needs that is secure against relativist reduction. Taken 
further, the capability approach developed in the pathbreaking work of Nobel Laureate economist Amartya Sen understands well-being in terms of the capabilities a person has. For example, poverty can be understood as the deprivation of capabilities and the onus is on government to remedy this, if possible (Taylor-Gooby 2008, p. 36). Lastly, desertbased claims are founded on the view that some quality or activity of a particular group imposes an obligation on society to provide them with certain services. Examples of such arguments are claims that motherhood or contribution through work or in war are deserving of social support, and that the duty to provide it should be borne by the state (Taylor-Gooby 2008, p. 36).

The United Nations Population Fund (UNFPA) (2013) points out that before 1997, most development agencies of the United Nations pursued a "basic needs" approach. In their work, they had identified basic requirements of beneficiaries and either supported initiatives to improve service delivery or advocated for their fulfillment. However, the UNFPA and its partners now work to fulfill the rights of people, rather than the needs of beneficiaries (emphasis added). This is an important distinction, because an unfulfilled need leads to dissatisfaction, while a right that is not respected leads to a violation. Hence, redress or reparation can be legally and legitimately claimed. A human rights-based approach also seeks to reinforce the capacities of duty bearers (usually governments) to respect, protect, and guarantee these rights. It aims to address development complexities holistically, taking into consideration the connections between individuals and the systems of power or influence. And it endeavors to create dynamics of accountability (UNFPA 2013). It can be noted from the foregoing that the United Nations has been advancing and clarifying dialogs and perspectives around human rights for decades, starting with the Universal Declaration of Human Rights in 1948. In the last two decades, governments around the world were nudged, in one way or another, by the United Nations and its agencies, toward rights-based approaches. Some of them actually ended up enshrining social rights in their Constitutions. As the world became more globalized, the role of the United Nations in this area became clearer and focused. Nonetheless, "despite the shrinking nature of our global community, the state is still central to the creation of the proper environment for the fulfillment of these rights. The state can enact measures to respect, protect, and fulfill basic human rights. The state can open up the political space so that democratic participation can become a reality. And the state can regulate the activities of other transnational economic actors whose practices violate basic human rights protections" (Felice 2010, p. 87). This is a very challenging issue, especially in developing countries and Africa in particular where there are many despotic governments. As for Africa, Sewpaul (2016, p. 13) contends that leaders have not taken responsibility for their complicity in gross human rights violations, corruption, and criminalization of the state and should not use culture as an excuse for the denial of civil and political rights.

Therefore, human rights are said to be rights which are held by virtue of nothing than our humanity (Wood 2014). One cannot say "human rights" of course without saying both "human" and "rights." The importance of drawing attention to the "human" component of "human rights" is to introduce a core concept: that of the right-holder. A right-holder, very simply is the person who has the right in question (Orend 2002). In this regard, human rights as exercised are rights that are actually enjoyed. They are needs that are satisfied by individuals regardless of the sources of these rights. They may be due to declarations (ideals), Constitutions (enactments), or to none of these (Wronka 1998). Crucially, human rights do not diminish with age. When age is used as a proxy for competency and functional well-being, many aspects of a person's life are threatened, including the basic rights of independence, security, and dignity. Moreover, impairment itself does not diminish the importance of these rights or the role of policies in ensuring that they are met (Cox 2015). The arteries that deliver wellbeing to older persons and ensure that they maintain a certain standard of living, which is acceptable and commensurate with a middle income country such as South Africa, are social welfare services among other social services. The former are defined by policies that particularly ensure that older persons fulfill their rights as guaranteed by the Constitution. In this case, the "fundamental issue concerning human rights is constructing policies enabling human rights to apply to everyone, not just selected individuals and groups" (Reichert 2011, p. 6). Such policies should ensure that human rights as exercised are rights that are actually enjoyed (Wronka 1998).

When examining older persons' human rights in South Africa, it is important to appraise the overall situation of human rights in the country. This broader picture is important, as it will proffer insights into the way the human rights of all South Africans are secured, or not, by the government and how they are violated by some citizens. Even though significant strides have been made since 1994 to entrench human rights in the country, many challenges abound in this area due to a number of factors. For example, Human Rights Watch (2016) observes that there is an erosion of the public's confidence in the South African government's willingness to tackle human rights violations, corruption, and respect for the rule of law. It further argues that the government has failed to ensure that an estimated half-million children with disabilities have access to basic education. Rights groups in the same period expressed concerns about the government's failure to develop a national strategy to combat the high rate of violence against women and the continued underreporting of rape (Human Rights Watch 2016). Furthermore, the government was accused of failing to hold accountable those responsible for xenophobic attacks on the businesses and homes of 
refugees, asylum-seekers, and migrants between March and May, 2015 (Human Rights Watch 2016). Also, Amnesty International (2017, p. 329) made startling revelations which suggest that human rights are being excessively violated in South Africa:

Police used excessive force against protesters. Torture, including rape, and other ill-treatment of people in police custody continued to be reported. Xenophobia and violence against refugees, asylum-seekers and migrants resulted in deaths, injuries and displacement. Women and girls, particularly those in marginalized communities, continued to face gender inequality and discrimination. Lesbian, gay, bisexual, transgender and intersex (LGBTI) people were subjected to discrimination and hate crimes, including killings. Human rights defenders were attacked.

Given this theoretical background, it can be said that human rights emerge out of a particular history and sociopolitical and economic context; hence, the next section closely examines the South African context.

\section{Examining the South African Context}

After almost 350 years of colonialism and apartheid, South Africa was liberated in 1994. Specifically, this was after the elections of 27 April 1994. In the past, the discrimination and exclusion of the majority African population from social, political, and economic avenues of advancement were institutionalized via various policies and legislation. In the main, the colonial-apartheid policies and legislation had ensured that Africans were locked into the lower segments of the society through inferior education and menial jobs. Even though the other races, such as the Coloreds (mixed-race people) and Indians, had suffered some degree of discrimination and exclusion, their lives had not been severely undermined by the colonial-apartheid state in the same way it had done for the African majority. It was in this atmosphere that the social welfare system was established to cater to the needs of whites. It can be argued that a welfare system that was developed in this context had advanced the ideals of colonialism and apartheid. In regard to older persons, South Africa's colonialapartheid welfare state was inextricably bound up with the state's concerns to safeguard the well-being of elderly whites. Hence, the legislative foundations of South Africa's welfare state were firmly laid when the 1928 Old Age Pensions Act was enacted. According to Seekings (2007), in the mid-1940s, the South African state extended to its African (or "native") subjects the old-age pensions that were provided to white (or "European") and "colored" people. It also started to concern itself with their education, physical health, and moral well- being. However, the African old age pension was far lower than the pensions of other races, especially of the whites.

In 1994, the new government which was led by the African National Congress (ANC) - a former liberation movementinstituted a transformation process across all sectors of the country in order to create a new society that would be inclusive and offer opportunities to all South Africans irrespective of race, gender, ethnic origin, and sexual orientation. To achieve this goal, first, the Reconstruction and Development Program (RDP) policy framework was developed by the ANC, to inform the content and pace of development. The RDP is referred to as an integrated, coherent socio-economic policy framework. It had sought to mobilize both the people and the country's resources toward the final eradication of apartheid, and the building of a democratic, non-racial, and non-sexist society (ANC 1994). Second, a new democratic Constitution was enacted in 1996. The Constitution of 1996 (Act no. 108) (as well as its forerunner the Interim Constitution of 1993) was able to imbue the country's policies and legislation with its ideals of, inter alia, democracy, participation, and human rights. The Constitution's socio-economic clause, namely, the Bill of Rights (which was a novelty) affirmed the democratic values of human dignity, equality, and freedom (Republic of South Africa 1996).

The South African Constitution brings to the fore the notion of entitlements and entwines social welfare service provision with the idea of rights:

The inclusion of economic, social and cultural rights (socio-economic rights) in the 1996 Constitution of South Africa is aimed at advancing the socioeconomic needs of the poor in order to uplift their human dignity. The Constitutional protection of these rights is an indication of the fact that the Constitution's transformative agenda looks beyond merely guaranteeing abstract equality (Mbazira 2009, p. 1).

Socio-economic rights, which are translated into social welfare services as well as other social services, are enshrined in the Constitution of South Africa. For example, Section 26 of the Constitution states that "everyone has the right to have access to adequate housing. The state must take reasonable legislative and other measures, within its available resources, to achieve the progressive realization of this right." In addition, Section 27 recognizes that "everyone has the right to have access to health-care services (encompassing reproductive health-care) sufficient food and water, and social security, including, if they are unable to support themselves and their dependents, appropriate social assistance." Furthermore, Section 28 enshrines the rights of children and notes that "every child has the right to basic nutrition, shelter, basic health-care services and social services", while Section 29 entrenches the right to education: "everyone has 
the right to a basic education, including adult basic education, and to further education" (Republic of South Africa 1996). As some of the foregoing initiatives were taking place, in October 1994, the Department of Social Welfare began planning for the development of a White Paper for Social Welfare that was to provide a framework for the transformation of the whole welfare sector. Eventually, a new social welfare policy was adopted in South Africa in 1997, and it replaced the old one which was discriminatory and exclusionary.

In the past, service delivery was from a social treatment perspective, and it was based on a social treatment approach. It was also informed by the medical model that solely focused on remediation, social pathology, and individual clinic practice. It was based on an understanding of deficits, which needed to be diagnosed and treated (Patel 2005). According to Patel (2005), p. 98):

South Africa's developmental approach to social welfare evolved from the country's unique history of inequality and the violation of human rights as a result of colonialism and apartheid. This history, experience and meaning of oppression for the majority of South Africans together with a long tradition of human agency and social action to change these conditions shaped the construction of the new society. Consequently, social welfare thinking and practice were infused with notions of transformation and human emancipation and an acknowledgement that reconciliation and healing the divisions of the past were critical to building a united South Africa based on democratic values, social justice and human rights.

The developmental approach to social welfare or social development which was adopted in South Africa and enunciated in the White Paper for Social Welfare (1997) can be defined as a process of planned social change designed to promote the well-being of the population as a whole within the context of a dynamic multifaceted development process (Midgley 1995). Patel (2005, p. 98) asserts that "the developmental perspective to social welfare in South Africa is firmly rooted in a rights-based approach. Its goals include achieving social justice, a minimum standard of living, equitable access and equal opportunity to services and benefits, and a commitment to meeting the needs of all South Africans with special emphasis on the needs of the most disadvantaged in the society." It is undergirded by a service delivery model which is distinguished by the following features:

- Rights-based approach to service delivery;

- Integrated family-centered and community-based services;

- Generalist approach to service delivery; and

- Community development and developmental welfare services (Patel 2005, p. 156).
The Ministry's White Paper for Social Welfare (1997) envisaged that the new social welfare system would build a selfreliant nation in partnership with all stakeholders through an integrated social welfare system which maximized its existing potential, and which was equitable, sustainable, accessible, people-centered, and developmental. Furthermore, it was supposed to have facilitated the provision of appropriate developmental social welfare services to all South Africans, especially those living in poverty, those who are vulnerable, and those who have special needs. This was seen as taking place through the provision of services which were rehabilitative, preventative, and developmental. In addition, protective services and facilities, as well as social security, including social relief programs, social care programs, and the enhancement of social functioning would complement the former services (Ministry of Welfare and Population Development 1997). The Ministry's White Paper for Social Welfare (1997) argued that there was a need for the country to shift away from the notion of "care of the aged" to "ageing," which it defined as a holistic and positive approach, that recognizes ageing as a natural phase of life without denying the special needs of older persons. It also noted that the basic principle underlying ageing is to enable older persons to live active, healthy, and independent lives for as long as possible (Ministry of Welfare and Population Development 1997, p. 5). The Ministry's White Paper for Social Welfare (1997) also looked at the dispensation on ageing in South Africa, which at the time did not take demographic realities into account. For instance, the white population was significantly older than the rest of the population.

The government also enacted legislation that aimed to protect the rights and dignity of older persons. For instance, the Older Persons Act 13 of 2006 was passed to:

(a). Maintain and promote the status, well-being, safety, and security of older persons;

(b). Maintain and protect the rights of older persons;

(c). Shift the emphasis from institutional care to communitybased care in order to ensure that an older person remains in his or her home within the community for as long as possible;

(d). Regulate the registration, establishment, and management of services and establishment and the management of residential facilities for older persons; and

(e). Combat the abuse of older persons (Republic of South Africa 2006, p. 4).

South Africa also adheres to international conventions that seek to safeguard the well-being and human rights of elderly people, for instance the United Nations' Madrid Plan of Action that focuses on three priority areas: older persons and development; advancing health and well-being into old age; and ensuring an enabling and supportive environment 
(United Nations 2002). Others are the African Union Policy Framework and Plan of Action on Ageing (2002), which commits member states to advance policy actions aimed at benefitting older persons, and the African Charter on Human and Peoples' Rights (“African Charter”).

Notwithstanding the highlighted innovations in the welfare sector, there are still gaps in the social welfare policy and the whole welfare sector in general. For instance, despite lauding the implementation of the developmental social welfare approach, Lombard (2008, p. 166) concedes that "areas of tardy progress in implementing the White Paper include delivery on its international, regional and national mandate to address the structural causes of poverty and inequality and the lack of a unified human resource strategy for social welfare." Patel and Selipski (2010, p. 72) who reviewed South Africa's social welfare policy and legislation also seem to echo Lombard's sentiments. They assert that progress has been made in aligning policies with the Constitution, international conventions, and the rights-based approach to developmental social welfare. But they admit that, despite their broad support, these policies still cause grave concerns as regards their effective implementation. Some of the mentioned challenges and more were cited by the Comprehensive Report on the Review of the Ministry's White Paper for Social Welfare (1997) which was finalized by the Department of Social Development in 2016 (Department of Social Development 2016). The last part of the paper will focus on this report and tease out some of the shortcomings it cites that relate to older persons' well-being.

\section{The Situation of Older Persons' Human Rights in Post-Apartheid South Africa}

Any discussion relating to older persons needs to move from the premise that these people are a vulnerable group. Most of them are usually frail due to their advanced years. Perhaps, it is due to this vulnerable state that older persons continue to face various challenges in post-apartheid South Africa. The violation of their human rights is taking place despite the above-mentioned progress in the country since the advent of democracy in 1994. The dire situation of older persons has been highlighted by many actors for a number of years now. For example, the former Minister of Social Development, Dr. Zola Skweyiya, who served in this portfolio from 1999 to 2009, was very concerned about the plight of older persons in South Africa. Skweyiya had presided over a host of reforms that were aimed at protecting older persons. He had also made older persons a key priority during his 10-year tenure as minister (Skweyiya 2006). However, the situation seems to be worsening:

Older persons continue to lack access to adequate health and basic education, to suffer from gender discrimination and abuse, and to be threatened with economic isolation with no prospect of securing employment. Further, due to the country's high unemployment rate, and as recipients of state-funded social grants, many older persons have become responsible for financially supporting their family members; this situation is further exacerbated by the impact of HIV/AIDS, and the fact that so many children are left orphaned by the premature death of their parents (South African Human Rights Commission 2015, p. 6).

It is the contention of this discussion that the main issue which is eroding older persons' human rights is poverty. From poverty emerge other social ills which negatively impact on the older persons' human rights. Indeed, many older persons in South Africa are poor. For instance, in 2011, the majority of older persons in South Africa were classified as poor (40\%). The highest proportions of poor elderly persons were found in Limpopo and Eastern Cape provinces (77.1 and 64.4\% respectively). These two provinces account for a quarter of all elderly persons in South Africa. The highest proportion of elderly persons that were categorized as rich resided in the Western Cape (57.5\%) and Gauteng (50.4\%). Within these provinces, fewer than $10 \%$ of elderly persons were poor. In contrast, less than $5 \%$ of elderly persons in Limpopo were rich. These vast differences in the proportions of elderly persons who were categorized as being rich or poor point to the high levels of inequality in socio-economic status among elderly persons across the provinces of South Africa (Statistics South Africa 2014b). The foregoing scenario is disconcerting and as such, it is important to get a clearer picture of this population when discussing its human rights. According to the Older Persons Act 13 of 2006, an older person means a person who, in the case of a male, is 65 years of age or older and, in the case of a female, is 60 years of age or older (Republic of South Africa 2006). According to Statistics South Africa (2014b, p. iv), the number and proportion of elderly persons aged 60 years and older relative to those aged 59 and younger increased over the period 1996-2011. The number has increased from 2.8 million in 1996 to 4.1 million in 2011, and the proportions were from $7.1 \%$ in 1996 to $8.0 \%$ in 2011. Projections show that the older population will continue to increase, and by 2030 , there will be approximately seven million elderly persons in South Africa. The composition and distribution of older persons reflect noticeable differences between sexes, population groups, ethnic groups, and regions. Significantly, sex variations show that old age in South Africa is highly feminized. The sex ratio, a key measure of sex composition, increased from 64 to 66 elderly men per 100 elderly women over the period 1996-2011, suggesting an improvement in health among men (Statistics South Africa 2014b, p. iv). 
Since 1994, the South African government has attempted to address poverty of older persons through the provision of the old age grant or pension. In order for older persons to access the old age pension, they must be South African citizens with a South African Identity Document (ID). The old age grant is means-tested, and eligibility is based on the age of the beneficiary. The age criterion was equalized for both men and women in 2010 at 60 years. Before this, women were only eligible to receive the grant when they turned 60 years, while men could access it when they turned 65 years. However, after 2010 , both men and women are now able to access the old age pension after they turn 60 years. The old age pension is the largest in terms of government social assistance budget expenditure. There were 3.1 million older persons who were beneficiaries of this grant by 30 September 2015 (National Treasury 2010), and the number will more than likely increase in the near future, due to the lowering of mortality rates in this age cohort. The old age grant has been lauded by many commentators as an alleviator of poverty:

For instance, old age pensions operate as a very extensive and effective poverty alleviation scheme in South Africa. These are essentially distributive in nature; they reach more rural communities than urban and benefit more women than men. As a result, the Old Age Grant has assisted in enhancing the status of the elderly, as they have become wage earners and breadwinners (Makiwane 2011, p. 6).

The foregoing position is echoed by other research studies and scholars alike such as those by Economic Policy Research Institute (EPRI) (2004); Patel and Triegaardt (2008); and Plagerson and Ulriksen (2015), among others.

To the contrary, this paper argues that the old age pension inadvertently exacerbates the violation of older persons' human rights. This is because of the way the old age pension is framed by the government as an anti-poverty measure and the manner in which some South Africans perceive it as an income for households and not something that is exclusively for the aged. This discussion concurs with the assertions of Potts (2012, p. 85) that the old age pension creates a network of dependency in which entire households are dependent on the pension income of one individual and use this assistance for sustenance rather than seeking employment and self-sufficiency. Furthermore, the findings of a research study by Frisoli (2016, pp. 16-17) are seriously taken into consideration:

Besides entire households being dependent on the pensions of these older people, which constitutes financial abuse on its own, these older people were sometimes abused by their families because of their pension. Older persons reported losing control of their money when family members demanded that they hand it over. This was a source of great emotional stress for them. Financial abuse also takes the form of children expecting older persons to care for grandchildren and perform housework without being paid. Sometimes older persons were expected to pay for grandchildren's food, shelter, clothing and school fees. Older people, because of their physical limitations, are also easy targets for assault and robbery, especially after receiving their pension money. These are often combined with rape of older women.

Some of the above assertions bring into sharp focus something that is considered as social capital by some scholars but which may result in the violation of older persons' human rights. This refers to caregiving. Indeed, many older persons in South Africa are involved in caregiving. Culturally, there is an expectation that they should care for their grandchildren. With HIV/AIDS devastating families and communities and resulting in high numbers of orphans, many older persons have become caregivers in South Africa. Even though some of the aged may want to be caregivers or even enjoy it, it does not mean that the situation is all rosy here. Arguably, caregiving in some situations ends up in the violation of older persons' human rights. A research study by Mutemwa and Adejumo (2014) observes:

The findings of this study highlight the health challenges of elderly people caring for children orphaned by AIDS, either due to re-parenting at an old age or as a result of losing children and relatives to AIDS. The elderly experienced physical exhaustion as a challenge of caring for children orphaned by AIDS, since the capacity of their bodies is now reduced, and they have to meet the physical, emotional and spiritual needs of the children as well as providing them with food, clothing and shelter. Lack of sleep, dizziness, elevated blood pressure, low glucose levels and asthma were also aggravated by either contemplating how to fend for these children or owing to the fact that the orphans were very stubborn and took the elderly people for granted (Mutemwa and Adejumo 2014, p. 344).

Furthermore, Mutemwa and Adejumo (2014, p. 341) point out that "elderly people often complain about problems such as depression, stress and burn-out, feelings of inadequacy, helplessness, guilt and loss of self-esteem and confidence" after being overburdened with caregiving responsibilities.

The Comprehensive Report on the Review of the Ministry's White Paper for Social Welfare (1997) by the Department of Social Development (2016), brought to the fore certain pitfalls relating to the implementation of South Africa's social welfare policy. In this last section of the paper, 
some of the findings of the report which relate to older persons are brought to the fore. By highlighting the shortcomings of the report, it is argued here that such gaps in service delivery have the potential to negatively impinge on the human rights of older persons. According to the Department of Social Development (2016) residential services for older people were repeatedly named by respondents who participated in the review's research as among the most untransformed areas of social welfare service delivery. Despite having streamlined and deracialized the services for older persons almost 20 years ago, it was discovered that:

In ten homes white and black residents were physically separated at the time of the audit, and the residents did not seem to receive the same quality and standard of service. In some cases the families indicated that they would not let their relative stay in the home if it became racially integrated (Department of Social Development 2016, p. 110).

In the foregoing report, elder abuse was raised by respondents as a concern across provinces, with a widespread perception that this problem was rampant. For example, about $28 \%$ of household respondents knew of some older person who was being abused at the time of their interview. The abuse was sometimes characterized as attempts by the abusers to get access to old age grants. The report also asserts that abuse can also occur when behavior linked to dementia and Alzheimers is seen as reflecting bewitchment of the older person. Elder abuse was also raised in relation to the scarcity, or complete lack of, safe beds in residential facilities (Department of Social Development 2016). The report notes that another issue that impeded older persons from accessing their old age pension and other services was lack of information, as many of them were not aware that firstly such services existed and secondly that they were entitled to such services. Indeed, an inability of many older persons to access basic services, due to lack of information, means that their fundamental rights guaranteed in the Constitution are not being met (South African Human Rights Commission 2015).

\section{Conclusion}

In ending this discussion, it must be stated that merely putting in place rights-based policies and legislation in a transitory society like South Africa, where there are high levels of poverty and income inequality, is merely the first step toward the safeguarding of the rights of citizens in general and older persons in particular. Therefore, right-based policies should not be seen as ends in themselves. It was speculated at the outset that despite the many positive changes having taken place in the country in general and the welfare sector in particular, after 1994, older persons' human rights were not being entirely fulfilled. Hence, there was a need to shed more light on this issue. Crucially, it was pertinent to ascertain why the human rights of older persons were being violated in a country where all the country's policies and legislation are right-based. Both the reports of the Human Rights Commission and the Department of Social Development which this paper cited were able to show that the vestiges of colonialism and apartheid, as exemplified by high levels of unemployment, poverty, and inequality as well as a culture of human rights violation, were still existing parallel to the rights-based policies and legislation. Therefore, there is a need to bridge this divide through policies and programs that are evidence-based research processes.

\section{References}

African National Congress (ANC). (1994). The reconstruction and development program (RDP). Johannesburg: Umanyo.

African Union (AU). (2002). Policy Framework and Plan of Action on Ageing. Retrieved from https://au.int/sites/default/files/pages/ 32900-file-protocol_on the rights_of older_persons_e.pdf

Amnesty International. (2017). Amnesty International Report 2016/17: The State of the World's Human Rights. London: Amnesty International.

Chesterman, J. (2005). Civil rights: how indigenous Australians won formal equality. Queensland: University of Queensland Press.

Cox, C. B. (2015). Social policy for an aging society: a human rights perspective. New York: Springer.

Davids, N. (2013). Rape of elderly women on the increase. Retrieved from http://www.timeslive.co.za/thetimes/2013/01/08/Rape-ofelderly-women-on-the-increase 1.

Department of Social Development (DSD). (2016). Comprehensive report on the review of the white paper for social welfare, 1997. Pretoria: DSD.

Economic Policy Research Institute (EPRI). (2004). The Social and Economic Impact of South Africa's Social Security System. Retrieved from http://epri.org.za/wp-content/uploads/2011/03/ rp37.pdf.

Estes, C. L. (2001). Social policy and ageing: a critical perspective. Thousand Oaks: Sage Publication.

Felice, W. F. (2010). The global new deal: economic and social, human rights in world politics (2nd ed.). Lanham: Rowman \& Littlefield Publishers, Inc..

Frisoli, A. (2016). The South African elderly: Neglect, social contribution and the HIV/AIDS epidemic. Retrieved fromhttp://academicworks. cuny.edu/cgi/viewcontent.cgi?article $=2267 \&$ context=gc_etds.

Holden, C. (2005). Social policy and political economy: a tale of (at least) two disciplines. Social Policy \& Society, 4(2), 173-181.

Holder, C., \& Reidy, D. (2013). Introduction. In C. Holder \& D. Reidy (Eds.), Human rights: the hard questions (pp. 1-20). Cambridge: Cambridge University Press.

Human Rights Watch. (2016). South Africa: Events of 2016. Retrieved from https://www.hrw.org/world-report/2017/country-chapters/ south-africa.

Lombard, A. (2008). The implementation of the white paper for social welfare: a ten-year review. The Social Work PractitionerResearcher, 20(2), 154-173. 
Makiwane, M. (2011). The older persons and their relationship with younger generations in South Africa. Retrieved from http://www.google. co.za/url?sa $=$ t\&rct $=$ j\&q $=\&$ esrc $=$ s\& source $=$ web $\&$ cd $=1 \& v e d=$ 0ahUKEwi42-7ih7DRAhWEKyYKHU6oC6oQFggZMAA\&url= http $\% 3 \mathrm{~A} \% 2 \mathrm{~F} \% 2 \mathrm{Fwww} . \mathrm{hsrc}$.ac.za\%2Fen\%2Fresearch-data\% 2Fktree-doc\%2F11617\&usg=AFQjCNE9ns6J_Zd_93bYDbBlM jNTz-aTg.

Marshall, T. H. (1950). Citizenship and social class. Cambridge: Cambridge University Press.

Mbazira, C. (2009). Litigating socio-economic rights in South Africa: a choice between corrective and distributive justice. Pretoria: Pretoria University Law Press.

Midgley, J. (1995). Social development: the developmental perspective in social welfare. London: SAGE Publications Ltd..

Ministry of Welfare and Population Development (1997). White paper for social welfare. Government Gazette, Vol. 386, No. 18166 (8 August). Pretoria: Government Printer.

Mubangizi, J. C. (2005). The protection of human rights in South Africa: a legal and practical guide. Lansdowne: Juta and Company.

Mutemwa, M., \& Adejumo, O. (2014). Health challenges of elderly people caring for children orphaned by AIDS in a community setting in South Africa. African Journal for Physical, Health Education, Recreation and Dance, 1(2), 336-347.

National Treasury. (2010). Budget Review. Pretoria: National Treasury.

Orend, B. (2002). Human rights: concept and context. Peterborough: Broadview Press.

Patel, L. (2005). Social Welfare \& Social Development in South Africa. Cape Town: Oxford University Press Southern Africa.

Patel, L., \& Selipski, L. (2010). Social welfare policy and legislation in South Africa. In L. Nicholas, J. Rautenbach, \& M. Maistry (Eds.), Introduction to social work (pp. 48-72). Claremont: Juta \& Company Ltd..

Patel, L., \& Triegaardt, J. (2008). South Africa: social security, poverty alleviation and development. In J. Midgley \& K. Tang (Eds.), Social security, the economy and development (pp. 85-109). New York: Palgrave Macmillan.

Plagerson, S., \& Ulriksen, M. S. (2015). Cash transfer programmes, poverty reduction and women empowerment in South Africa. Geneva: International Labour Organisation (ILO).

Potts, R. (2012). Social Welfare in South Africa: Curing or Causing Poverty? Retrieved from https://psujia.files.wordpress.com/2012/ 04/social welfare final.pdf.

Reichert, E. (2011). Social work and human rights: a foundation for policy and practice (2nd ed.). New York: Columbia University Press.
Republic of South Africa (RSA). (1996). Constitution of the Republic of South Africa, 1996 (Act No. 108 of 1996). Pretoria: Government Printer.

Republic of South Africa (RSA). (2006). Older persons act 13 of 2006. Pretoria: Government Printer.

Savides, M. (2016). Government wants life sentences for men who rape elderly women. Retrieved from http:/www.timeslive.co.za/ thetimes/2016/09/19/Government-wants-life-sentences-for-menwho-rape-elderly-women.

Seekings, J. (2007). Not a single white person should be allowed to go under: Swartgeever and the origins of South Africa's welfare state, 1924-1929. Journal of African History, 48(3), 375-394.

Sewpaul, V. (2016). Social work and human rights: an African perspective. In S. Hessle (Ed.), Human rights and social equality: challenges for social work (pp. 13-27). London: Routledge.

Skweyiya, Z. (2006). Skweyiya: Grandparents Day and launch of Social Development Month. Retrieved from http:/www.polity.org.za/printversion/skweyiya-grandparents-day-andlaunch-of-socialdevelopment-month-01102006-2006-10-01.

Smith, K. M. (2014). International human rights. Oxford: Oxford University Press.

South African Human Rights Commission (SAHRC). (2015). Investigative hearing into systemic complaints relating to the treatment of older persons. Johannesburg: SAHRC.

Statistics South Africa (StatsSA). (2014b). Census 2011: profile of older persons in South Africa. Pretoria: StatsSA.

Taylor-Gooby, P. (2008). Equality, rights and social justice. In P. Alcock, M. May, \& K. Rowlingson (Eds.), The Student's Companion to Social Policy ( $3^{\text {rd }}$ ed) (pp. $\left.34-41\right)$. Malden: Blackwell Publishing.

United Nations. (1994). A manual for schools of social work and the social work profession. New York: United Nations.

United Nations. (2002). Second World Assembly on Ageing, Madrid, Spain 8-12 April 2002. New York: United Nations.

United Nations Population Fund (UNFPA). (2013). ICPD and human rights: 20 years of advancing reproductive rights through UN treaty bodies and legal reform. New York: UNFPA, Center for Reproductive Rights (CRR).

Wood, K. (2014). Human rights. Basingstoke: Palgrave MacMillan.

Wronka, J. (1998). Human rights and social policy in the $21^{\text {st }}$ century: a history of the human rights and comparison of the United Nations Universal Declaration of Human Rights with the United States federal and state constitutions (revised edition). Lanham: University Press of America, Inc.. 